\title{
Colloidal gold-complexed chitosanase: a new probe for ultrastructural localization of chitosan in fungi
}

\author{
Jean Grenier, Nicole Benhamou and Alain Asselin*
}

Département de Phytologie, Faculté des Sciences de l'Agriculture et de l'Alimentation, Université Laval, Québec, Canada GIK 7P4

(Received 11 January 1991; revised 19 April 1991; accepted 26 April 1991)

\begin{abstract}
A chitosanase was purified from the intercellular fluid extract of chemically stressed barley (Hordeum vulgare) leaves. Purification was achieved by preparative PAGE involving separation under native conditions at pH 4.3 (Reisfeld system) followed by denaturing PAGE in the presence of SDS. One basic chitosanase with a molecular mass of $19 \mathrm{kDa}$ could hydrolyse chitosan and glycol chitosan of crustacean origin in addition to fungal chitosan isolated after treatment of Mucor mucedo cells with sodium hydroxide followed by extraction in acetic acid. This enzyme did not exhibit activity towards $\beta$-1,4-polymers such as chitin, cellulose or peptidoglycan (from Micrococcus luteus) after SDS-PAGE. The chitosanase was conjugated to colloidal gold at pH 9.5 and applied to fungal tissue sections or to isolated glycol chitosan, chitosan, cellulose or chitin. The chitosanase-gold complex reacted intensely with glycol chitosan and chitosan but did not bind to chitin or cellulose. The enzyme-gold complex also labelled chitosan isolated from $M$. mucedo. However, it did not react with $M$. mucedo cells in tissue sections. Labelling with the chitosanase-gold complex was easily detected over cell walls of Fusarium oxysporum f. sp. radicis-lycopersici spores and hyphae as well as over cell walls of Ophiostoma ulmi, Aspergillus niger and Colletotrichum lindemuthianum. No binding was observed with Pythium ultimum.
\end{abstract}

\section{Introduction}

Chitin, chitosan and cellulose are the most ubiquitous $(1 \rightarrow 4)-\beta$-linked polysaccharides of fungal cell walls (Wessels \& Sietsma, 1981). Chitin [a polymer of $N$ acetylglucosamine; $(1 \rightarrow 4)$-2-acetamido-2-deoxy- $\beta$-D-glucan] can be easily revealed at the ultrastructural level with the use of chitinase- or wheat germ agglutinin-gold complexes (Benhamou \& Asselin, 1989). Cellulose (1 $\rightarrow 4-$ $\beta$-D-glucan) can also be visualized using an exoglucanase-gold complex (Benhamou, 1989). By contrast, chitosan (partially or fully $N$-deacetylated chitin) has, until now, been difficult to localize by cytochemical approaches because of the absence of specific probes. Chitosan has been reported to occur in the cell walls of Phycomyces, Mucor, Zygorhynchus and Choanephora (Bartnicki-Garcia, 1968; Letourneau et al., 1976; Datema et al., 1977b). It also occurs in the spore and hyphal walls of Agaricus (Novaes-Ledieu \& Garcia Mendoza, 1981), in spores of rust (Hadwiger \& Line, 1981) and Saccharomyces (Briza et al., 1988), and in Fusarium hyphae and spores (Hadwiger et al., 1981). In some

Abbreviations: IF, intercellular fluid; PDA, potato dextrose agar; PR, pathogenesis-related; TEM, transmission electron micrograph.
Zygomycetes, it has been demonstrated that chitosan derives from $N$-deacetylation of nascent chitin by chitin deacetylase (Araki \& Ito, 1988; Trudel \& Asselin, 1990). Exogenous chitosan and chitosan oligosaccharides from fungal cell walls can elicit various defence reactions in plants, including the synthesis and accumulation of callose (Kendra et al., 1989).

Moreover, chitosan has become a natural biodegradable cationic polymer with commercial applications ranging from pharmaceutical to cosmetic and agricultural uses (Sandford \& Hutchings, 1987). Despite the recognized biological significance of chitosan and chitosan derivatives, there is still no probe allowing in situ detection of this polysaccharide.

In this paper, we report the conditions required for tagging a barley chitosanase with colloidal gold particles and the use of the gold complex for localizing chitosan in spore and hyphal cell walls of several fungi.

\section{Methods}

Chemicals. All chemicals for electrophoresis, analytical-grade mixedbed resin AG 501-X8 (20-50 mesh), protein molecular mass markers and Coomassie Brilliant Blue R250 were from Bio-Rad. Protein concentration was determined with the Bio-Rad protein assay reagent. 
Glycol chitosan, chitosan and all other chemicals were from Sigma. Glycol chitin was synthesized as previously described (Trudel \& Asselin, 1989). The degree of deacetylation of substrates has been reported previously (Grenier \& Asselin, 1990).

Plant material, induction of pathogenesis-related $(P R)$ proteins and intercellular fluid extracts. All plants were grown under greenhouse conditions. Barley seedlings (Hordeum vulgare cv. Léger) were grown for $25 \mathrm{~d}$ before $5 \mathrm{~cm}$ leaf sections were made and floated for $3 \mathrm{~d}$ on $100 \mu \mathrm{M}-\mathrm{AgNO}_{3}$ (Asselin et al., 1985). Intercellular fluid (IF) extracts were prepared by vacuum infiltration followed by low-speed centrifugation (Parent \& Asselin, 1984).

$P A G E$. Proteins were separated in one-dimensional native or denaturing $15 \%(\mathrm{w} / \mathrm{v})$ polyacrylamide gel systems as previously described (Trudel et al., 1989). Proteins were stained with Coomassie Brilliant Blue R250 followed by aqueous silver nitrate.

Detection of hydrolase activity after PAGE. Chitinase activity was detected by Calcofluor White M2R staining after lysis of glycol chitin as substrate, as described for tobacco PR proteins (Trudel et al., 1989). Chitosanase activity was detected after hydrolysis of $0.01 \%$ glycol chitosan or $0.05 \% M$. mucedo chitosan as substrate in the gel matrix. Bands were detected with Calcofluor White M2R staining, as for chitinase activity, or by staining the intact glycol chitosan with Coomassie Brilliant Blue R250 (Grenier \& Asselin, 1990). After electrophoresis, SDS-gels were first incubated at room temperature in $200 \mathrm{ml}$ sodium acetate buffer $(0.01 \mathrm{M}, \mathrm{pH} 5.0)$ with $1 \%(\mathrm{v} / \mathrm{v})$ purified Triton X-100 (Grenier \& Asselin, 1990). After $20 \mathrm{~min}$, the buffered Triton X-100 solution was replaced and gels were incubated for $18 \mathrm{~h}$ at $37^{\circ} \mathrm{C}$ with gentle shaking. Chitosanase activity was also detected after native PAGE. Chitosanase activity in gels run at $\mathrm{pH} 4.3$ was detected by an overlay $7.5 \%(\mathrm{w} / \mathrm{v})$ polyacrylamide gel $(0.75 \mathrm{~mm}$ thick) containing $0.01 \%$ glycol chitosan. Transfer of proteins to the overlay gel was made by blotting according to Audy et al. (1988). Staining of native gels was exactly as for SDS-gels. Hydrolase activity against carboxymethyl (CM)-cellulose was evaluated after SDS-PAGE by Calcofluor staining (Côté et al., 1991). Detection of lysozyme activity after SDS-PAGE was performed as previously described (Audy et al., 1989).

Isolation and analysis of chitosan from Mucor mucedo. Chitosan was isolated from a 2-d-old $M$. mucedo culture after autoclaving in $\mathrm{NaOH}$ and solubilizing in acetic acid (White et al., 1979). Chitosan was hydrolysed in $6 \mathrm{M}-\mathrm{HCl}$ for $18 \mathrm{~h}$ at $105^{\circ} \mathrm{C}$. TLC was performed with cellulose-coated plates for $7 \mathrm{~h}$ in $n$-butanol/pyridine $/ 0.5 \mathrm{M}-\mathrm{HCl}(5: 3: 2$, by vol.). Spots were detected with ninhydrin.

Purification of a single barley chitosanase. IF extracts $(80 \mathrm{ml})$ from chemically stressed barley leaves were concentrated tenfold by freezedrying. IF extracts were subjected to native PAGE in $15 \%(w / v)$ polyacrylamide gels ( 10 gels, $800 \mu \mathrm{l}$ per gel) at pH 4.3 (Reisfeld system). The lower band corresponding to chitosanase activity was cut out and the protein was eluted in distilled water $(5 \mathrm{ml}$ per gel slice) overnight at $4{ }^{\circ} \mathrm{C}$. The eluate was filtered through a Millipore membrane $(0.22 \mu \mathrm{m})$ and freeze-dried. The eluate was resuspended in $6 \mathrm{ml}$ distilled water and subjected to SDS-PAGE in $15 \%(\mathrm{w} / \mathrm{v})$ polyacrylamide gels containing $0.01 \%$ glycol chitosan (seven gels, $800 \mu$ l eluate per gel). Bands corresponding to chitosanase activity at $19 \mathrm{kDa}$ were cut out and incubated twice for $15 \mathrm{~min}$ in $0.01 \mathrm{M}$-sodium acetate (pH 5.0) in $25 \%$ $(\mathrm{v} / \mathrm{v})$ propan-2-ol. After rinsing gel pieces with water, they were incubated overnight at $37^{\circ} \mathrm{C}$ with shaking in $0.01 \mathrm{M}$-sodium acetate (pH 5-0). The eluate was filtered through a Millipore membrane $(0.22 \mu \mathrm{m})$ and concentrated by freeze-drying. One milligram of purified chitosanase was recovered.

Fungal isolates and culture conditions. The isolate of Colletotrichum lindemuthianum (Sacc. and Magn.) Briosi and Cav. used in this study was kindly provided by Dr D. Mazau, Centre de Physiologie Végétale, Université Paul Sabatier, Toulouse, France. It was cultured at $23^{\circ} \mathrm{C}$ in a defined, solid medium containing (g per $1000 \mathrm{ml} \mathrm{H}_{2} \mathrm{O}$ ): glucose $(2 \cdot 8)$, $\mathrm{MgSO}_{4} .7 \mathrm{H}_{2} \mathrm{O}(1 \cdot 3), \mathrm{KH}_{2} \mathrm{PO}_{4}(2 \cdot 7)$, mycological peptone (2.0), yeast extract $(10 \cdot 0)$ and agarose $(20 \cdot 0)$.

The isolate of Fusarium oxysporum f. sp. radicis-lycopersici, Jarvis and Shoemaker was obtained from Mr P. O. Thibodeau, Complexe Scientifique, Ste-Foy, Québec, Canada. It was cultured at $22^{\circ} \mathrm{C}$ on potato dextrose agar (PDA, Difco) and periodically re-inoculated and re-isolated from ripe tomato fruits.

The isolate of Ophiostoma ulmi (Buism.) Nannf. was provided by $\mathrm{Dr}$ G. Ouellette, Centre forestier des Laurentides, Ste-Foy, Québec, and was isolated from an infected elm tree in Québec, and periodically reinoculated and re-isolated from elms. It was grown at $22^{\circ} \mathrm{C}$ on PDA medium.

The isolate of Aspergillus niger Van Tiegh was obtained from the culture collection maintained at the Département de Phytologie, Universite Laval. The fungus was cultured on PDA medium at $22^{\circ} \mathrm{C}$.

The isolate of Pythium ultimum Trow was kindly provided by $\mathrm{Dr} R$. Bélanger, Université Laval. It was cultured on PDA medium at $22^{\circ} \mathrm{C}$.

Mucor mucedo Linn. ex Fr. was described previously (Trudel \& Asselin, 1990).

Tissue processing for electron microscopy. Samples from actively growing colonies of each fungus, or polysaccharides in agarose plugs, were fixed with $3 \%(\mathrm{v} / \mathrm{v})$ glutaraldehyde in $0.1 \mathrm{M}$-sodium cacodylate buffer ( $\mathrm{pH} \mathrm{7.2)} \mathrm{for} 2 \mathrm{~h}$ at room temperature, dehydrated in a graded ethanol series and embedded in Epon 812. Some samples were postfixed with $1 \%(\mathrm{w} / \mathrm{v})$ osmium tetroxide in sodium cacodylate buffer for $1 \mathrm{~h}$ at $4{ }^{\circ} \mathrm{C}$, before dehydration. Ultrathin sections were collected on Formvar-coated nickel grids and processed for gold cytochemistry.

Preparation of chitosanase-gold complex. Colloidal gold with an average particle diameter of $15 \mathrm{~nm}$ was prepared according to Frens (1973) by reducing aqueous tetrachloroauric acid solution $(0.01 \%, \mathrm{w} / \mathrm{v})$ with $1 \%(\mathrm{w} / \mathrm{v})$ sodium citrate. The optimal $\mathrm{pH}$ for binding the colloidal gold sol to chitosanase was estimated to be 9.5. The minimal amount of chitosanase necessary for full stabilization of the gold sol was determined by adding $100 \mu$ colloidal gold ( $\mathrm{pH} 9.5$ ) to $10 \mu \mathrm{l}$ of serial

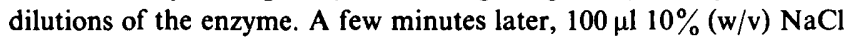
was added and flocculation estimated visually. The minimum concentration of chitosanase necessary to stabilize the gold sol at $\mathrm{pH} 9.5$ was estimated to be $3 \mu \mathrm{g} \mathrm{ml}^{-1}$. A fivefold excess $(150 \mu \mathrm{g})$ was used to fully stabilize $10 \mathrm{ml}$ colloidal gold.

For preparation of the chitosanase-gold complex, about $150 \mu \mathrm{g}$ of the enzyme was dissolved in $100 \mu \mathrm{l}$ distilled water and mixed with $10 \mathrm{ml}$ colloidal gold at $\mathrm{pH} 9 \cdot 5$. To further stabilize the gold sol, five drops of PEG $20000(1 \%, w / v)$ were added to the mixture. After centrifugation at 13000 r.p.m.for $60 \mathrm{~min}$, the supernatant was discarded and the darkred pellet was resuspended in $0.5 \mathrm{ml} 0.1 \mathrm{M}-\mathrm{PBS}$ ( $\mathrm{pH} \mathrm{6.0)}$ ) containing $0.02 \%$ PEG 20000. The gold-complexed chitosanase was stored at $4{ }^{\circ} \mathrm{C}$ until required.

Preparation of exoglucanase- and ovomucoid-gold complexes. The exoglucanase, a $\beta$-1,4-cellobiohydrolase ( $\beta$-glucosidase; EC 3.2.1.21), was purified in a five-step procedure from a cellulase produced by the fungus Trichoderma harzianum Rifai (Benhamou, 1989). It was complexed to colloidal gold at $\mathrm{pH} 9.0$ as previously described (Benhamou et al. 1987). Briefly, $500 \mu \mathrm{g}$ of the enzyme was mixed with $10 \mathrm{ml}$ colloidal gold at $\mathrm{pH} 9.0$, and the pellet recovered after centrifugation was resuspended in $0.5 \mathrm{ml} 0.1 \mathrm{M}-\mathrm{PBS} / \mathrm{PEG}$ ( $\mathrm{pH} \mathrm{6.0)}$ ).

Wheat germ agglutinin (WGA), a lectin with $N$-acetylglucosamine binding specificity, was used in a two-step procedure for the localization of chitin. Due to its low molecular mass, this lectin could not be directly complexed to colloidal gold (Benhamou, 1988). Ovomucoid, a high molecular mass protein isolated from egg white, 


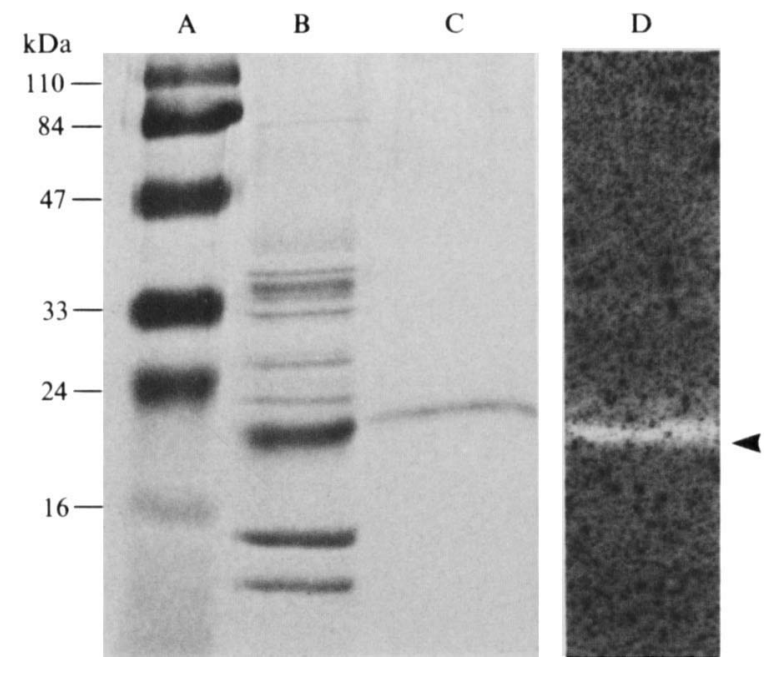

Fig. 1. Electrophoretogram of barley intercellular fluid extract, purified barley chitosanase and chitosanase activity against $M$. mucedo chitosan. Prestained molecular mass markers (lane A, $10 \mu \mathrm{l}, 100 \mu \mathrm{g}$ ) (110 kDa, phosphorylase $b ; 84 \mathrm{kDa}, \mathrm{BSA} ; 47 \mathrm{kDa}$, ovalbumin; $33 \mathrm{kDa}$, carbonic anhydrase; $24 \mathrm{kDa}$, soybean trypsin inhibitor; $16 \mathrm{kDa}$, lysozyme), barley intercellular fluid extract (lane $\mathrm{B}, 10 \mu \mathrm{l}$, $60 \mu \mathrm{g}$ ) and electrophoretically purified barley $19 \mathrm{kDa}$ chitosanase (lane $\mathrm{C}, 10 \mu \mathrm{l}, 6 \mu \mathrm{g})$ were separated by SDS-PAGE $(15 \%, \mathrm{w} / \mathrm{v})$. Proteins were stained with Coomassie Brilliant Blue R-250 followed by silver nitrate. Purified barley chitosanase $(10 \mu \mathrm{l}, 6 \mu \mathrm{g})$ was also subjected to SDSPAGE in a gel containing $M$. mucedo chitosan (see Methods) at a final concentration of $0.05 \%$ (lane D). $M$. mucedo chitosan was initially dissolved in $10 \%(\mathrm{v} / \mathrm{v})$ acetic acid. After renaturation and lysis by chitosanase for $18 \mathrm{~h}$ at $37^{\circ} \mathrm{C}$ in buffered Triton X-100, chitosanase activity was detected by Coomassie Brilliant Blue R-250 staining (Grenier \& Asselin, 1990). Lysis appears as a white band against a blue background.

was used as a second-step reagent because of its high affinity for WGA. The protein was complexed to gold at $\mathrm{pH} 5 \cdot 3$, and the pellet recovered after centrifugation was resuspended in $0.5 \mathrm{ml} \mathrm{PBS} / \mathrm{PEG}$ ( $\mathrm{pH} \mathrm{6.0)}$ ).

Cytochemical labelling. For cytochemical labelling with chitosanase and exoglucanase-gold complexes, grids were first incubated for $5 \mathrm{~min}$ on a drop of PBS/PEG (pH 6.0) and then transferred to a drop of the enzyme-gold complex for $30 \mathrm{~min}$ at room temperature in a moist chamber. Grids were thoroughly washed with PBS ( $\mathrm{pH} 7.4$ ), rinsed with distilled water and contrasted with uranyl acetate and lead citrate before examination with a JEOL $1200 \mathrm{EX}$ electron microscope at $80 \mathrm{kV}$.

For cytochemical labelling with the WGA/ovomucoid-gold complex, grids were first incubated on a drop of PBS (pH 7.4) for $5 \mathrm{~min}$, then transferred to a drop of WGA $\left(25 \mu \mathrm{g} \mathrm{ml}^{-1}\right.$ in PBS, $\mathrm{pH} \mathrm{7.4)}$ for $1 \mathrm{~h}$ at room temperature, and finally incubated on a drop of ovomucoidgold complex diluted $1: 30$ in PBS/PEG (pH 6.0). After washing, grids were counterstained as described above.

Cytochemical controls. Specificity of the labellings with the different probes was assessed by several control tests: (1) incubation with the chitosanase or the exoglucanase-gold complex to which an excess of the corresponding substrate had been previously added; (2) incubation with the uncomplexed enzyme followed by incubation with the goldcomplexed enzyme; (3) incubation with WGA to which was previously added $N, N^{\prime}, N^{\prime \prime}$-triacetylchitotriose followed by incubation with the ovomucoid-gold complex; (4) incubation with the ovomucoid-gold

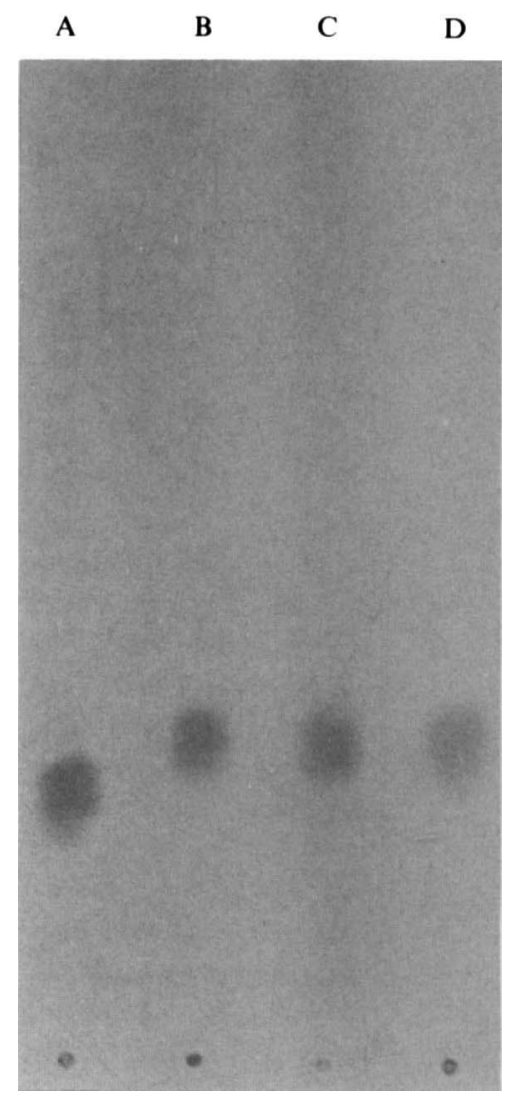

Fig. 2. TLC of crustacean and isolated $M$. mucedo chitosan after $\mathbf{H C l}$ hydrolysis. Commercial crustacean chitosan and isolated Mucor chitosan (see Methods) were subjected to $6 \mathrm{M}-\mathrm{HCl}$ hydrolysis at $105^{\circ} \mathrm{C}$ for $18 \mathrm{~h}\left(10 \mu \mathrm{g} \mu \mathrm{l}^{-1}\right.$, final concentration). D-Galactosamine (lane A), Dglucosamine (lane B), Mucor hydrolysed chitosan (lane C) and commercial hydrolysed chitosan (lane D) (all $10 \mu \mathrm{g}$ ) were separated by TLC on a cellulose-coated TLC plate $(20 \times 20 \mathrm{~cm})($ see Methods). Spots were detected with ninhydrin.

complex, the WGA step being omitted; and (5) incubation with a protein-gold complex such as BSA-gold complex.

\section{Results}

\section{Purification of a basic chitosanase from intercellular fluid extracts of stressed barley leaves}

We recently reported that several plant chitosanases accumulated in the IF extracts of chemically stressed leaf tissue (Grenier \& Asselin, 1990). Certain basic chitosanases even exhibited some lytic activity against fungal spores. This prompted the idea that some plant chitosanases from IF extracts could be valuable probes for localizing chitosan in fungal cells. One basic chitosanase of $19 \mathrm{kDa}$ was purified by two cycles of preparative PAGE (native PAGE followed by SDS-PAGE). The source of the enzyme was from barley IF extracts (Fig. 1, 

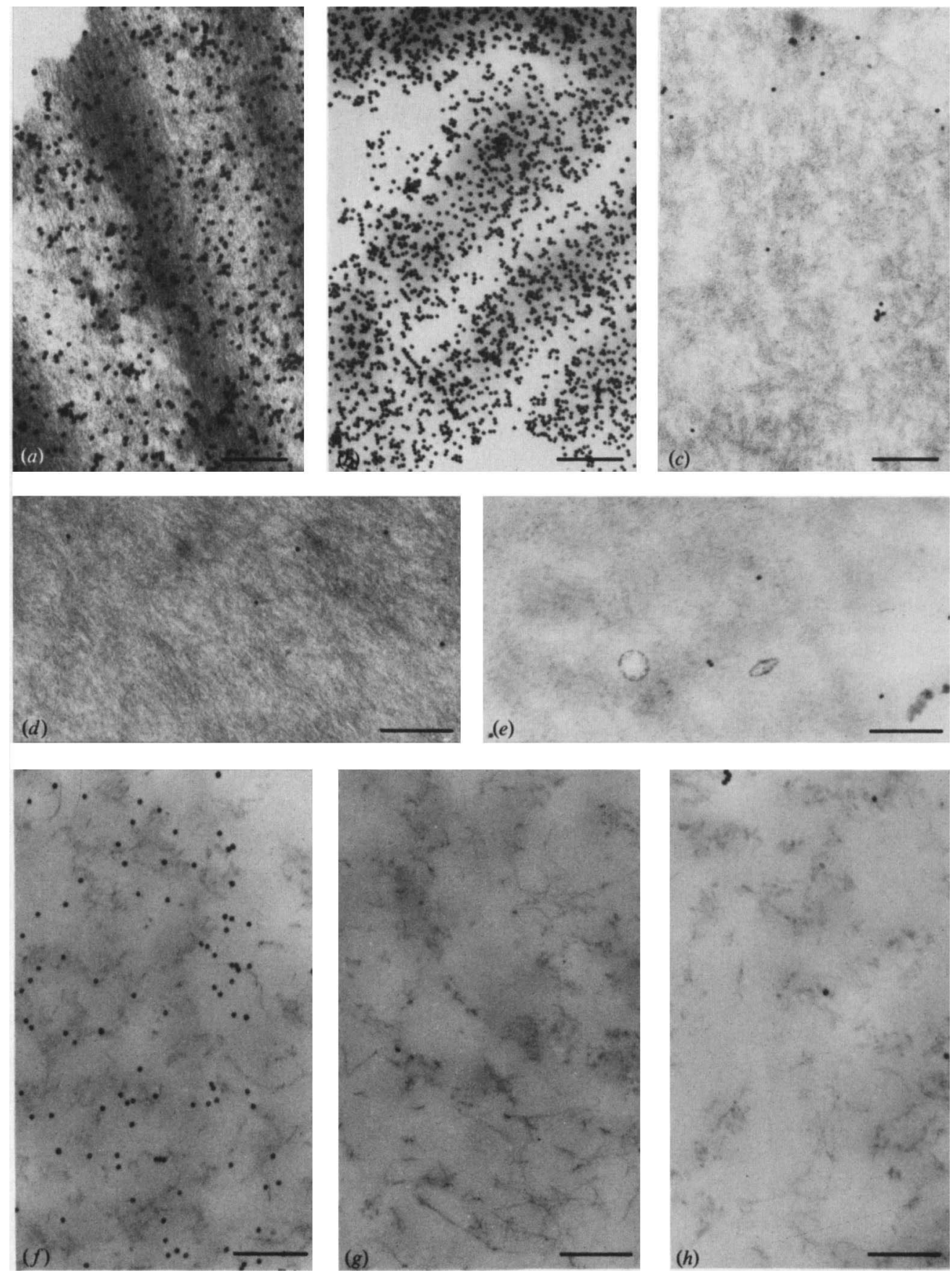

Fig. 3. Transmission electron micrographs (TEMs) of embedded commercial chitosan $(a, d)$, glycol chitosan $(b, e)$, chitin $(c)$ and embedded chitosan isolated from $M$. mucedo cell walls $(f, g, h)$. Samples were incubated with the chitosanase-gold complex $(a, b, c, f)$, the gold-complexed exoglucanase $(d, e, g)$ or the WGA/ovomucoid-gold complex $(h)$. Bars, $0.25 \mu \mathrm{m}$.

lane B). The purified chitosanase exhibited a single band at $19 \mathrm{kDa}$ after SDS-PAGE and staining with Coomassie Brilliant Blue followed by silver nitrate (Fig. 1, lane C) when compared to molecular mass markers (Fig. 1, lane $\mathrm{A}$ ). The purified chitosanase also exhibited a single band of activity (Fig. 1, lane D) when assayed in a gel system containing fungal chitosan as substrate (Grenier \& Asselin, 1990).

\section{Substrate specificity of purified chitosanase}

By using new gel assays (Trudel \& Asselin, 1989; Grenier \& Asselin, 1990, Côté et al., 1991), the purified chitosanase was tested for its activity against several polysaccharides containing a $\beta$-1,4-glucan backbone. The chitosanase did not exhibit activity towards chitin (this work and Grenier \& Asselin, 1990), CM-cellulose or 

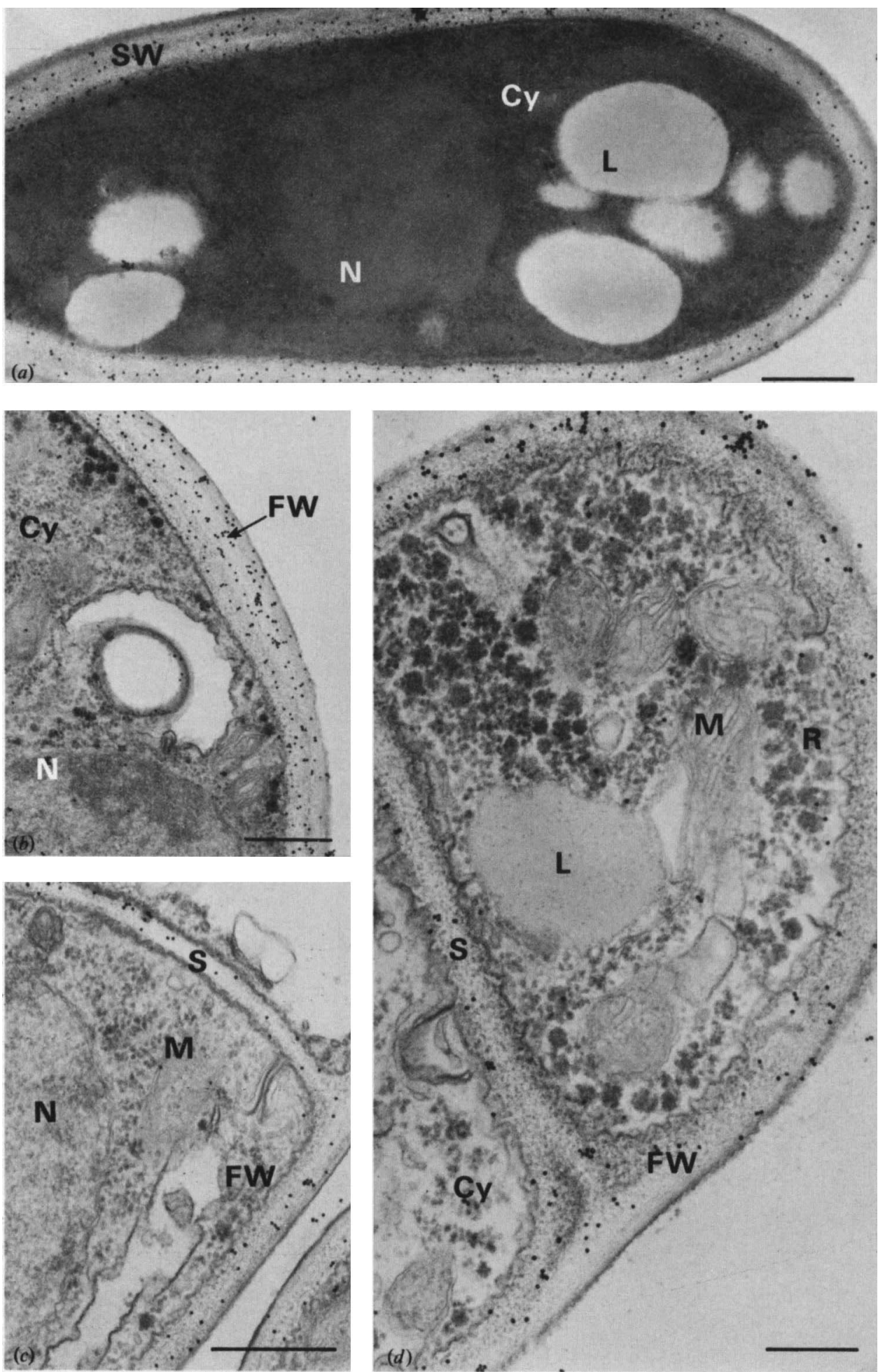

Fig. 4. TEMs of $F$. oxysporum f. sp. radicis-lycopersici in culture labelled with the chitosanase-gold complex. (a) Spore, (b) young hypha and $(c, d)$ older hyphae. Abbreviations: $\mathrm{Cy}$, cytoplasm; FW, fungal wall; $\mathrm{L}$, lipid body; $M$, mitochondrion; $N$, nucleus; $R$, ribosomes; $\mathrm{S}$, septum; SW, spore wall. Bars, $0 \cdot 5 \mu \mathrm{m}$.

peptidoglycan (Micrococcus luteus). However, it exhibited lytic activity not only against glycol chitosan $(94 \%$ deacetylation) and chitosan $(74 \%$ deacetylation) of crustacean origin (data not shown), but also against chitosan isolated from Mucor mucedo (Fig. 1, lane D). $M$. mucedo represents one of the best sources of fungal 

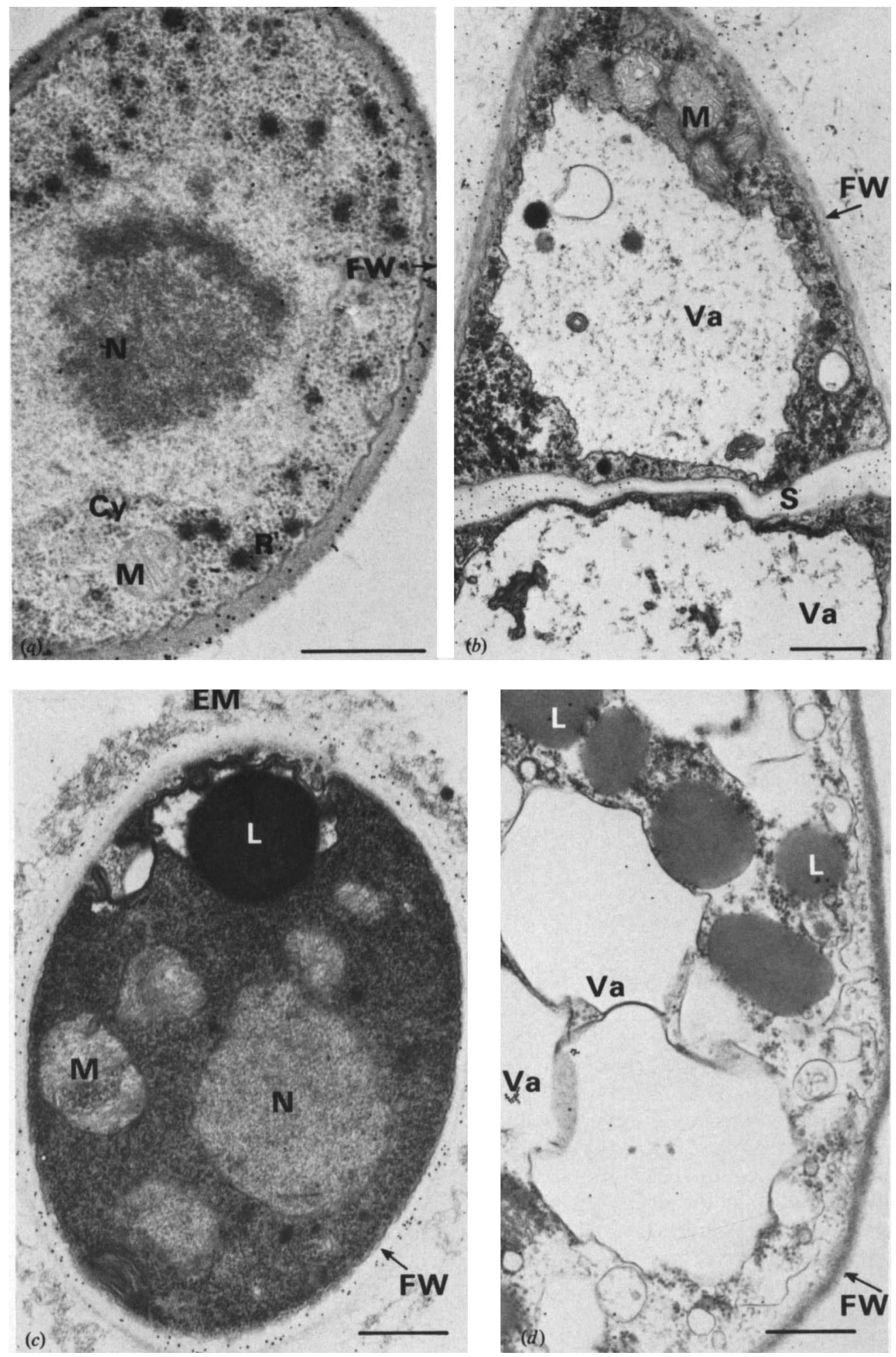

Fig. 5. TEMs of $O$. ulmi (a), C. lindemuthianum (b), A. niger (c) and P. ultimum $(d)$ in culture labelled with the chitosanase-gold complex. Abbreviations are defined in the legend to Fig. 4 except: EM, extracellular material; Va, vacuole. Bars, $0.5 \mu \mathrm{m}$.

chitosan (White et al., 1979) and chitosan from Mucorales is highly deacetylated (70-95\%) (Fenton \& Eveleigh, 1981; McGahren et al., 1984). In order to assess the identity of the isolated Mucor chitosan, the extract was subjected to $\mathrm{HCl}$ hydrolysis and analysed by TLC. The hydrolysed Mucor chitosan yielded D-glucosamine (Fig. 
2, lane C) in a way similar to that of commercial crustacean glycol chitosan (Fig. 2, lane D). In this TLC system, reference D-galactosamine could be separated from D-glucosamine (Fig. 2, lanes A and B, respectively).

\section{Cytochemical localization of chitosan}

Application of the gold-complexed chitosanase to sections of embedded commercial chitosan (Fig. $3 a$ ) and glycol chitosan of crustacean origin (Fig. $3 b$ ) resulted in the deposition of numerous gold particles. By contrast, chitin failed to react positively with the gold-complexed enzyme as judged by the very few scattered gold particles observed over sections of embedded material (Fig. 3c). Both chitosan and glycol chitosan were unlabelled following incubation with the exoglucanase-gold complex (Fig. $3 d, e$ ), indicating that cellulosic subunits were absent.

Chitosan extracted and purified from $M$. mucedo cell walls was substantially labelled with the chitosanasegold complex (Fig. $3 f$ ) but did not react with either the exoglucanase-gold complex (Fig. $3 g$ ) or the WGA/ovomucoid-gold complex (Fig. $3 h$ ). M. mucedo chitosan has been shown in this work to be sensitive to purified barley chitosanase (Fig. 1, lane D).

Incubation of sections from spores of $F$. oxysporum $\mathrm{f}$. sp. radicis-lycopersici with the gold-complexed chitosanase, resulted in a heavy labelling of cell walls (Fig. $4 a$ ). Labelling appeared to be uniformly distributed although in some cases a preferential accumulation of gold particles was observed over the innermost wall layers (Fig. 4a). Cytoplasm, nucleus, lipid bodies and other organelles were always free of labelling. The thick wall of young emerging hyphae of $F$. oxysporum $\mathrm{f}$. sp. radicislycopersici were also intensely and specifically labelled (Fig. $4 b$ ). In apparently older hyphal cells, the thinner wall was labelled by scattered gold particles (Fig. $4 c, d$ ). Although weak compared to that of spores, this labelling was specifically associated with cell walls and septa, and did not occur over cytoplasm and organelles (Fig. $4 d$ ).

Application of the gold-complexed chitosanase to sections of $O$. ulmi resulted in the deposition of gold particles over the outermost wall layers (Fig. $5 a$ ). Almost no labelling occurred over the cytoplasm or organelles. A significant cell wall labelling was also observed over $C$. lindemuthianum cell walls (Fig. $5 b$ ). Gold labelling appeared to be of higher intensity at the triangular junction between the wall and septum (Fig. $5 b$ ). Labelling was found to be mainly associated with the outermost wall layers of $A$. niger hyphal cells, whereas the extracellular, fibrillar matrix was free of gold particles (Fig. 5c). Of all the fungi tested, $P$. ultimum was the only one that did not react with the chitosanase-gold complex as judged by the absence of significant labelling (Fig. 5d).

Adsorption of the gold-complexed chitosanase with glycol chitosan prior to section labelling yielded negative results with $O$. ulmi (data not shown). By contrast, labelling was neither eliminated nor reduced when the gold-complexed enzyme was previously incubated with glycol chitin or $\beta$-1,4-glucans from barley (data not shown). All other control tests resulted in an absence of labelling over both material sections and embedding resin.

\section{Discussion}

Chitosanases have been identified as a class of enzymes different from chitinases (e.g. EC 3.2.1.14) and lysozymes (e.g. EC 3.2.1.17) (Monaghan et al., 1973). Up to now, chitosanases have been characterized mostly from bacterial (Pelletier \& Syguch, 1990, and references therein) and fungal sources (Reyes et al., 1985). More recently, some plant $P R$ proteins have been shown to be extracellular chitosanases (Grenier \& Asselin, 1990).

The barley chitosanase was chosen as a probe for four reasons. First, it is much easier to purify a chitosanase from an IF extract that contains less than 30 proteins than from whole tissue extracts. Second, the barley extracellular enzyme is resistant to proteolysis as is the case for the well-known PR proteins. Third, barley represents an inexpensive and readily available source of tissue for enzyme purification. In fact, other cereals (such as wheat) can also be used as good sources of plant chitosanases. Fourth, several microbial chitosanases also exhibit cellulase activity (Pelletier \& Syguch, 1990) which would preclude their use as specific probes for chitosan localization.

The barley chitosanase-gold complex interacted with fungi known to contain chitosan in their cell walls, including Colletotrichum (Siegrist \& Kauss, 1990) and Fusarium (Hadwiger et al., 1981). However, to our knowledge this is the first evidence for the occurrence of chitosan in the cell walls of Ophiostoma and Aspergillus. $A$. niger cell walls are known to contain $\alpha-(1 \rightarrow 4)$ galactosamine polymers. Because such galactosamine polymers display similar conformation and functional properties to chitosan (Yokoyama et al., 1989), the barley chitosanase was tested for its activity against the Physarum polycephalum galactosamine polymer in sclerotia (McCormick et al., 1970). No activity could be found against this polygalactosamine polymer (data not shown), thus indicating that chitosan was recognized.

It is important to note that chitosan is operationally defined as partially or fully deacetylated chitin. The specificity of labelling should eventually take into 
account the fact that there is evidence for complete (Datema et al., 1977b) or partial deacetylation (Mol \& Wessels, 1987) with fungal chitin. It is noteworthy that the basic $19 \mathrm{kDa}$ barley chitosanase (chitosanase 6 , Grenier \& Asselin, 1990) was found to exhibit lytic activity not only against chitosan but also against fungal spores such as those from $F$. oxysporum $\mathrm{f}$. sp. radicislycopersici, Verticillium albo-atrum and $O$. ulmi (Grenier \& Asselin, 1990). Results of the present work confirmed that this chitosanase was able to specifically bind to chitosan present in the cell walls of these fungi (results not shown for $V$. albo-atrum). However, the enzyme was not able to reveal chitosan in $M$. mucedo cell sections while it could easily hydrolyse chitosan isolated from the same fungal culture. Even though chitosan is a major wall component of Zygomycetes, it may not be readily accessible to chitosanase (at least to this barley chitosanase). The substrate may be masked by tightly bound components, such as anionic glycuronans and inorganic polyphosphates (Datema et al., 1977a). This has been well illustrated for chitosan in Mucorales cell walls (McGahren et al., 1984).

Numerous chitosanase-binding molecules were detected in the spore walls of $F$. oxysporum f. sp. radicislycopersici. Although this observation correlates well with the recent finding that spores of this pathogenic fungus were somewhat lysed by the enzyme in polyacrylamide gels (Grenier \& Asselin, 1990), the biological significance of this accumulation is unclear. One might suggest that the appreciable amount of chitosan in the walls of $F$. oxysporum f. sp. radicis-lycopersici spores contributes to strengthen the cell surface. This is in line with previous observations by Qureshi \& Tage (1970) that the ability of Fusarium to withstand adverse conditions was closely related to the presence of particular compounds in its thick-walled spores. Owing to its peripheral localization and its cationic properties, chitosan may also be involved in cell-cell recognition and/or attachment to host cells during pathogenesis.

A significant difference in the amount of chitosan was observed between spores and mycelium of $F$. oxysporum f. sp. radicis-lycopersici. A similar heterogeneity was recently reported in the case of cellulosic $\beta$-1,4-glucans which were found to be more abundant in spore than in mycelial walls (Benhamou et al., 1990). This raises the question of the relative value that should be given to the chemical composition of spore wall in the taxonomic classification of fungi. In the classification of BartnickiGarcia (1968), the Zygomycetes constitute a unique group containing chitosan along with chitin. The present cytochemical observations demonstrate that chitosan is more widely distributed in fungi than was previously thought.

The present results also suggest that the barley chitosanase may be of potential value not only for investigating the distribution of chitosan in fungi, but also to gain new insights into the role of chitosan during pathogenesis. Noteworthy in this context are the preliminary results showing that the level of wall-bound chitosan in C. lindemuthianum grown in culture markedly increases when the fungus develops in its host plant (unpublished results). This is in agreement with the reported involvement of chitosan fragments in plant defence (Kendra et al., 1989).

This work was supported by grants from the Natural Sciences and Engineering Research Council of Canada (NSERC) and the Conseil des Recherches en Pêche et Agro-Alimentaire du Québec (CORPAQ). We thank Mrs Céline Parent for typing the manuscript. Thanks are extended to Souad El Ouakfaoui for her collaboration and Sylvain Noël for excellent technical support.

\section{References}

ARAKI, Y. \& ITO, E. (1988). Chitin deacetylase. Methods in Enzymology 161, 510-514.

Asselin, A., Grenier, J. \& CôtÉ, F. (1985). Light-influenced extracellular accumulation of $b$ (pathogenesis-related) proteins in Nicotiana green tissue induced by various chemicals or prolonged floating on water. Canadian Journal of Botany 63, 1276-1283.

Audy, P., Trudel, J. \& Asselin, A. (1988). Purification and characterization of a lysozyme from wheat germ. Plant Science 58, 43-50.

Audy, P., Grenier, J. \& Asselin, A. (1989). Lysozyme activity in animal extracts after sodium dodecyl sulfate-polyacrylamide gel electrophoresis. Comparative Biochemistry and Physiology 92B, 523527.

BARTNICKI-GARCIA, S. (1968). Cell wall chemistry, morphogenesis, and taxonomy of fungi. Annual Review of Microbiology 22, 87-108.

Benhamou, N. (1988). Preparation and application of lectin-gold complexes. In Colloidal Gold Techniques and Applications, pp. 95-143. Edited by M. A. Hayat. New York: Academic Press.

BENHAMOU, N. (1989). Cytochemical localization of $\beta-(1 \rightarrow 4)$-D-glucans in plant and fungal cells using an exoglucanase-gold complex. In Electron Microscopy Reviews: Subcellular and Biomolecular Structure, pp. 123-138. Edited by J. R. Harris. London: Pergamon Press.

BenHamou, N. \& Asselin, A. (1989). Attempted localization of a substrate for chitinases in plant cells reveals abundant $N$-acetyl-Dglucosamine residues in secondary walls. Biology of the Cell 67, 341350 .

Benhamou, N., Chamberland, H., Ouellette, G. B. \& Pauzé, F. J. (1987). Ultrastructural localization of $\beta$-( $1 \rightarrow 4)$-D-glucans in two pathogenic fungi and in their host tissues by means of an exoglucanase-gold complex. Canadian Journal of Microbiology 33, 405-417.

Benhamou, N., Chamberland, H., Noël, S. \& Ouellette, G. B. (1990). Ultrastructural localization of $\beta$-1,4-glucan-containing molecules in the cell walls of some fungi: a comparative study between spore and mycelium. Canadian Journal of Microbiology 36, 149-158.

Briza, P., Ellinger, A., Wrikler, G. \& BreitenbaCh, M. (1988). Chemical composition of the yeast ascospore wall. The second outer layer consists of chitosan. Journal of Biological Chemistry 263, 11569 11574.

Côté, F., El Ouakfaoui, S. \& Asselin, A. (1991). Detection of $\beta$ glucanase activity on various $\beta-1,3-$ and $\beta$-1,4-glucans after native and denaturing polyacrylamide gel electrophoresis. Electrophoresis 12, 69-74.

Datema, R., VAN den Ende, H. \& Wessels, J. G. H. (1977a). The hyphal wall of Mucor mucedo. 1. Polyanionic polymers. European Journal of Biochemistry 80, 611-619. 
Datema, R., Wessels, J. G. H. \& Van den Ende, H. (1977b). The hyphal wall of Mucor mucedo. 2. Hexosamine-containing polymers. European Journal of Biochemistry 80, 621-626.

Fenton, D. M. \& EVELeigh, D. E. (1981). Purification and mode of action of a chitosanase from Penicillium islandicum. Journal of General Microbiology 126, 151-165.

FrENS, G. (1973). Controlled nucleation for regulation of the particle size in monodisperse gold suspensions. Nature Physical Science 241, 20-22.

GRENIER, J. \& ASSELIN, A. (1990). Some pathogenesis-related proteins are chitosanases with lytic activity against fungal spores. Molecular Plant-Microbe Interactions 3, 401-407.

HADWIGER, L. A. \& LiNe, R. F. (1981). Hexosamine accumulations are associated with the terminated growth of Puccinia striiformis on wheat isolines. Physiological Plant Pathology 19, 249-255.

Hadwiger, L. A., Beckman, J. M. \& Adams, M. J. (1981). Localization of fungal components in the pea-Fusarium interaction detected immunochemically with anti-chitosan and anti-fungal cell wall antisera. Plant Physiology 67, 170-175.

Kendra, D. F., Christian, D. \& Hadwiger, L. A. (1989). Chitosan oligomers from $F$ usarium solani/pea interactions, chitinase/ $\beta$-glucanase digestion of sporelings and from fungal wall chitin actively inhibit fungal growth and enhance disease resistance. Physiological and Molecular Plant Pathology 35, 215-230.

Letourneau, D. R., Deven, J. M. \& Manocha, M. S. (1976). Structure and composition of the cell wall of Choanephora cucurbitarum. Canadian Journal of Microbiology 22, 486-494.

MCCormick, J. J., Blomouist, J. C. \& RusCh, H. P. (1970). Isolation and characterization of a galactosamine wall from spores and spherules of Physarum polycephalum. Journal of Bacteriology 104, 1119-1125.

McGahren, W. J., Perkinson, G. A., Growich, J. A., Leese, R. A. \& Ellestad, G. A. (1984). Chitosan by fermentation. Process Biochemistry 8, 88-90.

Mol, P. C. \& Wessels, J. G. H. (1987). Linkages between glucosaminoglycan and glucan determine alkali-insolubility in walls of Saccharomyces cerevisiae. FEMS Microbiology Letters 41, 95-99.

Monaghan, R. L., Eveleigh, D. E., Tewarin, R. P. \& Reese, E. T. (1973). Chitosanase, a novel enzyme. Nature New Biology 245, 78-80.

Novaes-Ledieu, M. \& Garcia Mendoza, D. (1981). The cell walls of Agaricus bisporus and Agaricus campestris fruiting body hyphae. Canadian Journal of Microbiology 27, 779-787.
PARENT, J.-G. \& Asselin, A. (1984). Detection of pathogenesis-related proteins (PR or b) and of other proteins in the intercellular fluid of hypersensitive plants infected with tobacco mosaic virus. Canadian Journal of Botany 62, 564-569.

Pelletier, A. \& Syguch, J. (1990). Purification and characterization of 3 chitosanase activities from Bacillus megaterium P1. Applied and Environmental Microbiology 56, 844-848.

QURESHI, A. A. \& TAGE, O. T. (1970). Observations on chlamydospore production by Fusarium in a two-salt solution. Canadian Journal of Microbiology 16, 29-32.

Reyes, F., Lahoz, R., Martinez, M. J. \& Alfonso, C. (1985). Chitosanases in the autolysis of Mucor rouxii. Mycopathologia 89, 181-187.

SANDFord, P. A. \& Hutchings, G. P. (1987). Chitosan - a natural, cationic biopolymer: commercial applications. In Industrial Polysaccharides: Genetic Engineering, Structure/Property Relations and Applications, pp. 363-375. Edited by M. Yalpani. Amsterdam: Elsevier.

SiEgRIST, J. \& KaUSs, H. (1990). Chitin deacetylase in cucumber leaves infected by Colletotrichum lagenarium. Physiological and Molecular Plant Pathology 36, 267-275.

TRUDEL, J. \& Asselin, A. (1989). Detection of chitinase activity after polyacrylamide gel electrophoresis. Analytical Biochemistry 178, 362 366.

Trudel, J. \& Asselin, A. (1990). Detection of chitin deacetylase activity after polyacrylamide gel electrophoresis. Analytical Biochemistry 189, 249-253.

Trudel, J., AUDY, P. \& Asselin, A. (1989). Electrophoretic forms of chitinase activity in Xanthi-nc tobacco, healthy and infected with tobacco mosaic virus. Molecular Plant-Microbe Interactions 2, 315324.

Wessels, J. G. H. \& SieTSMa, J. H. (1981). Fungal cell walls : a survey. In Plant Carbohydrates II, pp. 352-394. Edited by W. Tanner \& F. A. Loewus. New York: Springer-Verlag.

White, S. A., Farina, P. R. \& Fulton, I. (1979). Production and isolation of chitosan from Mucor rouxii. Applied and Environmental Microbiology 38, 323-328.

Yokoyama, T., Murakami, E., Hasegawa, K., Tukada, S., Takagi, H., KADOWAKI, K. \& OISHI, K. (1989). Microbial production of polyhexosamine. In Chitin and Chitosan, pp. 333-343. Edited by G. Skjak-Braek, T. Anthonsen \& P. Sandford. London: Elsevier Applied Science. 